\title{
Impact of Agricultural Inputs on Agricultural GDP in Indian Economy
}

\author{
Tamma Koti Reddy*, Madhubanti Dutta \\ Department of Economics, IBS Hyderabad (A Constituent of ICFAI Foundation for Higher Education), Hyderabad, India \\ Email: ^tammamuralimanohar@gmail.com
}

How to cite this paper: Reddy, T.K. and Dutta, M. (2018) Impact of Agricultural Inputs on Agricultural GDP in Indian Economy. Theoretical Economics Letters, 8, 1840-1853.

https://doi.org/10.4236/tel.2018.810121

Received: April 9, 2018

Accepted: June 18, 2018

Published: June 21, 2018

Copyright $\odot 2018$ by authors and Scientific Research Publishing Inc. This work is licensed under the Creative Commons Attribution International License (CC BY 4.0).

http://creativecommons.org/licenses/by/4.0/ (c) (i) Open Access

\begin{abstract}
The paper aims to investigate the impact of Agricultural inputs on Agricultural Gross Domestic Product in Indian Economy using A Simple Regression Analysis for the period 1980-1981 to 2015-2016. Agricultural GDP is taken as the dependent variable and independent variables are taken as fertilizers, net irrigated area, pesticides, electricity, rainfall and usage of HYV seeds. The study reveals that the variables like fertilizers and net irrigated area are not statistically significant, which means they do not have a significant impact on agricultural GDP during the time period $1980-1981$ to $2015-2016$. The study further reveals that the variables like pesticides, electricity, rainfall and seeds are statistically significant and it is inferred that these variables have a significant impact on agricultural GDP during the aforementioned data period. The authors opine that the government can intervene in the working of the agricultural sector both from input side as well as from output side. The study highlights that the Reviving public sector investment is critical due to its multiplier effect on the overall GCF in the sector. Thus, there is a need to formulate a long-term perspective plan for rural infrastructure that focuses on infrastructural projects that have the highest total impact and strongest linkages.
\end{abstract}

\section{Keywords}

Net Irrigated Area, Fertilizers, Electricity, Rainfall, Agricultural GDP, Public Investment

\section{Introduction}

Indian Economy is mainly agrarian in nature and economy is rural centric. Being the largest industry in the country, in 1972-1973 nearly 73.9 percent of working population was engaged in agriculture and allied activities, and this percentage fell to 64.8 percent in 1993-1994 and 48.9 percent in 2011-2012 [1]. 
During the period 2011-2014 agriculture provided employment to 43 percent of the male workers and 60 percent of the female workers. Moreover it provides raw materials to our leading industries such as Cotton Textile, Jute, Sugar, Vanaspati Industries that are of basic importance to the national economy. The proportion of agricultural goods which are exported, amount to near about the total amount of our exports. Thus agriculture is an extremely important part of our economic structure. The average rate of growth of agricultural production in India during 1951-2006 has been around 3.0 percent per annum which is considerably lower as compared to that of 5.3 percent in China, 4.4 percent in Pakis$\tan$ and 4.1 percent in Indonesia. In the post-green revolution period annual growth rate (1967-1968 to2013-2014) was to the extent of 2.4 percent per annum. The growth rates of agriculture and allied sectors have been fluctuating: $1.5 \%$ in $2012-2013,5.6 \%$ in $2013-2014,-0.2 \%$ in $2014-2015,0.7 \%$ in $2015-2016$, and $4.9 \%$ in 2016-2017. The uncertainty in growth in agriculture is because $50 \%$ of agriculture is dependent on rainfall [2].

From 53.1 percent in 1950-1951, the share of agriculture and allied activities includes forestry and logging and fishing in GDP at factor cost declined to 29.6 percent in 1990-1991 and further to 13.9 percent in 2013-2014(at 2004-2005 prices).According to the new series with 2011-2012 as the base year the share of agriculture and allied activities in Gross Value Added (GVA) at basic prices was 16.5 percent in 2014-2015 and then fell to15.4 percent in 2015-2016. Gross Capital Formation (GCF) in agriculture as a proportion of total GCF has declined during the post-reform period. It was declined from 9.9percent in1990-1991 to 8.6 percent (at 1993-1994 price) in 2011-2012(2011-2012 price) and further fell to 7.8 percent in 2015-2016 [2].

The new economic policies followed by successive governments have brought about a serious crisis in Indian agriculture. The impact of falling prices of agricultural produce, declining per capita income, the decrease in the per capita consumption of food grains and increasing poverty in rural India have culminated in the crisis. The crisis in agriculture is also caused by the policy of shifting cultivation from traditional crops like Rice and Maize etc., to capital-intensive commercial crops. The proportion of area under cultivation between food crops and nonfood crops has recorded a change from 74:26 in 1950-1951 to 80:20 in 1980-1981 and then again reversed to $77: 23$ in 1990-1991 and then finally to 73:27 in 2013-2014. It clearly reflects a shift in area from non-food crops to food crops in the country. The main reason behind this shift is cultivation of food crops, now-a-days has become very much remunerative and productive due to the introduction of new technology in Indian agriculture. Inadequate finance, untimely finance and inconsistent or contradictory policies of the government have aggravated farmer's problems severely [3]. Agricultural production has been directly supported by subsidies to farm inputs such as fertilizers and irrigation in many developing countries, such as India. These policies generally benefit large farmers more than smallholders [4]. The growth in the productivity has been stagnant in recent years, resulting in a significant decline in the income of 
farmers. Agricultural growth contributes to economic growth through a forward linkage effect (agriculture providing food and raw materials to non-agricultural production), a backward linkage effect (agriculture consuming industrial products such as insecticide or tractors), inter-sector al transfers (agriculture contributes taxes and cheap labor to other sectors), and foreign exchange through agricultural exports [5]. At the outset, the paper aims to investigate the impact of Agricultural inputs on Agricultural Gross Domestic Product in Indian Economy. Agricultural sector is largely state controlled which resulted in widespread inefficiencies and distortions. Subsidies on inputs have helped a lot to secure food sufficiency, yet it has many negative impacts. It results in over use of inputs as inputs cost doesn't represent adequate market costs, farmers are unable to respond to market signals. They continue to use skewed mix of inputs as costs are borne by the government.

The present study discusses the impact of Agricultural inputs on Agricultural GDP in Indian economy for the period 1980-1981 to 2015-2016. It has also estimated the statistical significance of different inputs taken for study on Agricultural GDP. The present study contributes to the existing knowledge base on Indian Agriculture in a way that it estimates the impact of Agricultural inputs on Agricultural GDP using a simple regression analysis. For the purpose of the study only secondary data is taken for the period 1980-1981 to 2015-2016.So all the limitations of secondary data are found in the study. The results are particularly pertinent when considering economic growth prospects for countries where a majority of lab our force still depend upon agriculture.

The rest of the paper is organized as follows. The chapter gives the present progress of Agricultural sector in Indian economy in terms of yield of principal crops and India's position in world agriculture. The third chapter deals with trends in Agricultural inputs for the study period. The fourth chapter is about Impact of Agricultural inputs on Agricultural GSDP.The fifth chapter is about policy implications and conclusions

\subsection{Objectives of the Study}

1) To study the progress of Agricultural Sector in terms of production and productivity of Indian Economy in comparison with other economies across the world

2) To study the trends in Agricultural inputs used since 1980-81.

3) To study the impact of various agricultural inputs on Agricultural GDP growth rate of the Indian Economy.

\subsection{Literature Review}

According to NCAER Kharif Outlook Report [6] the slow or negative agricultural growth momentum in the recent years signifies that despite the sharp decline in rainfall, agriculture sector in India is yet to be completely weather-proof. The study further reveals that the advancements in farming practices and technology have limited the impact of adverse impact of monsoon failure on agricultural 
production. The study highlights that timely intervention by the government through formulation and effective implementation of crop contingency plans helped to mitigate the drought losses, but not fully. Bardhan [7] counter argues that the green revolution may not help in raising agricultural employment.

The Green Revolution in Asia was partly driven by intensive irrigation. In fact, only 4 percent of crop area in Africa is irrigated, versus 34 percent in Asia. Another factor that makes the Sub-Saharan African context different is the underdevelopment of infrastructure, which hinders market access and leads to high transportation costs. As a consequence, several geographically separate revolutions will have to take place across Sub-Saharan Africa [8]. Schultz (1964) stressed the importance of making inputs available to farmers (and increasing the capacity of industry to supply these inputs), generating new locally specific knowledge, and improving education about new seeds and technologies via extension services.

Garg et al. [9] state that the adoption of HYV of crops have helped in increasing income proportionate to the percentage of adoption in all groups of farmers with the adoption of HYV, the additional income per hectare has accounted for more than double the expenditure. It is also observed that technology is neutral to the size of the farm and it tends to reduce the disparities between the various groups of farms.

Ishwar C. Dhingra [10] has points out that the improved strains of seeds are essential for increasing agricultural production. Unless the farmer has good seeds of suitable varieties, he cannot get the best out of other inputs, such as irrigation, fertilizers, insecticides and machinery. With HYV seeds, it becomes possible for the farmer to take to intensive agriculture because of the resultant high yield and good economic returns.

\subsection{Research GAP}

The earlier review of literatures focuses on the role of agricultural inputs and the consequences for countries processes of structural change. The results of the few studies that have been carried out in India have been conflicting. There is therefore a gap in literature as far as a study on the effects of agricultural inputs on agricultural GDP in India is concerned. This study therefore sought to fill this research gap by answering one question: What is the relationship between agricultural inputs and agricultural GDP in Indian Economy?

\subsection{Methodology}

The study has used secondary data from different data sources like RBI, Hand Book of Statistics on Indian Economy, Economic Surveys, Agricultural Statistics at a glance and FAOSTAT etc for analysis. A simple regression analysis has been used here to establish relationship between agriculture GDP growth and growth in various inputs required in production process. The paper uses the data for variables such as fertilizer consumption, net irrigated area, pesticides consump- 
tion, electricity consumption and HYV seeds consumption.

Agriculture GDP $=\beta 1+\beta 2$ fertilizers $+\beta 3$ netirrigatedarea $+\beta 4$ pesticides $+\beta 5$ electricity $+\beta 6$ rainfall $+\beta 7$ seeds $+\mu$.

The Agriculture GDP growth rate is taken as the dependent variable and growth in fertilizers, net irrigated area, pesticides, electricity, rainfall and HYV seeds are taken as independent variables.

$\beta 1=$ Constant term (When value of all the independent variables are zero, the value of agriculture GDP).

$\beta 2=$ Unit $/ \%$ change in agriculture GDP due to 1 unit $/ \%$ increase in fertilizers.

$\beta 3=$ Unit $/ \%$ change in agriculture GDP due to 1 unit/\% increase in net irrigatedarea.

$\beta 4=$ Unit $/ \%$ change in agriculture GDP due to 1 unit $/ \%$ increase in pesticides.

$\beta 5=\mathrm{Unit} / \%$ change in agriculture GDP due to $1 \mathrm{unit} / \%$ increase in electricity.

$\beta 6=$ Unit $/ \%$ change in agriculture GDP due to 1 unit $/ \%$ increase in rainfall.

$\beta 7=$ Unit $/ \%$ change in agriculture GDP due to 1 unit $/ \%$ increase in seeds.

Here $\mu$ represents all the other variables that have not been included as independent variables due to unavailability of data in the given period. Our methodology will involve the minimization of the error term in order to avoid omitted variable bias.

Error term basically shows the presence of all those variables that has not been taken due to reasons like unavailability of data etc, but they have an impact on the dependent variable. So as a researcher, in order to avoid spurious regression, we should reduce the error term by taking as many variables as control variables, which in turn will give us accurate and unbiased results. Here in our paper we have dealt with the error term by taking as many control variables that impacts the dependent variable (Agriculture GDP), which will improve our prediction, reduce our error term and make it close to zero and avoid the problem of omitted variable bias, as mentioned earlier.

\section{Progress of Agricultural Sector in Indian Economy}

Table 1 provides information on the total population in the country and various categories agricultural workers depend on agricultural sector since 1951. According to the Census of 1951, the population of the country was 361.1 million. Since then, in a period of 60 years the population of the country has increased by more than 850 million. It is clear from the above table that the rate of growth of population during 1951-1961 was 1.96 percent per annum and further increased to 2.20 percent per annum during 1961-1971. The 1991 census also indicates that the annual rate of growth of population during the 1980s was 2.16 percent. The annual rate of growth rate of population has come down to 1.97 percent during 1991-2001 and further fell to 1.50 percent during 2001-2011. The proportion of rural population to the total population has shown a declining trend since 1951. The proportion of rural population to the total population has been decreased from 82.7 percent in 1951 to 68.9 percent in 2011. Total workers have 
Table 1. Population and agricultural workers (In Millions).

\begin{tabular}{|c|c|c|c|c|c|c|c|}
\hline \multirow[t]{2}{*}{ Year } & \multirow[t]{2}{*}{$\begin{array}{c}\text { Total } \\
\text { Population }\end{array}$} & \multirow{2}{*}{$\begin{array}{c}\text { Average } \\
\text { Annual } \\
\text { Exponential }\end{array}$} & \multirow[t]{2}{*}{$\begin{array}{c}\text { Rural } \\
\text { Population }\end{array}$} & \multirow{2}{*}{$\begin{array}{c}\text { Total } \\
\text { workers }\end{array}$} & \multicolumn{3}{|c|}{ Agricultural Workers } \\
\hline & & & & & Cultivators & $\begin{array}{l}\text { Agricultural } \\
\text { Laborers }\end{array}$ & Total \\
\hline (1) & (2) & (3) & (4) & (5) & (6) & (7) & (8) \\
\hline 1951 & 361.1 & 1.25 & $\begin{array}{l}298.6 \\
(82.7)\end{array}$ & 139.5 & $\begin{array}{c}69.9 \\
(71.9)\end{array}$ & $\begin{array}{c}27.3 \\
(28.1)\end{array}$ & $\begin{array}{c}97.2 \\
(69.7)\end{array}$ \\
\hline 1961 & 439.2 & 1.96 & $\begin{array}{l}360.3 \\
(82.0)\end{array}$ & 188.7 & $\begin{array}{c}99.6 \\
(76.0)\end{array}$ & $\begin{array}{c}31.5 \\
(24.0)\end{array}$ & $\begin{array}{l}131.1 \\
(69.5)\end{array}$ \\
\hline 1971 & 548.2 & 2.20 & $\begin{array}{l}439.0 \\
(80.1)\end{array}$ & 180.4 & $\begin{array}{c}78.2 \\
(62.2)\end{array}$ & $\begin{array}{c}47.5 \\
(37.8)\end{array}$ & $\begin{array}{l}125.7 \\
(69.7)\end{array}$ \\
\hline 1981 & 683.3 & 2.22 & $\begin{array}{l}525.6 \\
(76.9)\end{array}$ & 244.6 & $\begin{array}{c}92.5 \\
(62.5)\end{array}$ & $\begin{array}{c}55.5 \\
(37.5)\end{array}$ & $\begin{array}{l}148.0 \\
(60.5)\end{array}$ \\
\hline 1991 & 846.4 & 2.16 & $\begin{array}{l}630.6 \\
(74.5)\end{array}$ & 314.1 & $\begin{array}{l}110.7 \\
(59.7)\end{array}$ & $\begin{array}{c}74.6 \\
(40.3)\end{array}$ & $\begin{array}{l}185.3 \\
(59.0)\end{array}$ \\
\hline 2001 & 1028.7 & 1.97 & $\begin{array}{l}742.6 \\
(72.2)\end{array}$ & 402.2 & $\begin{array}{l}127.3 \\
(54.4)\end{array}$ & $\begin{array}{l}106.8 \\
(45.6)\end{array}$ & $\begin{array}{l}234.1 \\
(58.2)\end{array}$ \\
\hline 2011 & 1210.8 & 1.50 & $\begin{array}{l}833.7 \\
(68.9)\end{array}$ & 481.9 & $\begin{array}{l}118.8 \\
(45.1)\end{array}$ & $\begin{array}{l}144.3 \\
(54.9)\end{array}$ & $\begin{array}{l}263.1 \\
(54.6)\end{array}$ \\
\hline
\end{tabular}

Source: Registrar General of India. Note: (1) Figures within parentheses in col.4 are percentages to the total population; (2) Figures within parentheses in col.6 and 7are percentages to col.8; (3) Figures within parentheses in col.8 are percentage share of Agricultural workers in Total Workers.

been increased substantially from 135.9 m million in 1951 to 481.9 million in 2011. The dependence on agriculture is brought out by the fact that out of total workers 263.1 million has been engaged in (54.6 percent) has been engaged in Agriculture and allied activities in 2011.

In Table 1, the working force in the agricultural sector was distributed into cultivators and agricultural laborers. During the year 2011 there are 118.8 million cultivators and 144.3 million Agricultural Laborers across the country. It can be seen from the table the proportion of cultivators in the total Agricultural workers has declined from $71.9 \%$ in 1951 to $45.1 \%$ in 2011 , while the proportion of agricultural laborers has increased from $28.1 \%$ in 1951 to $54.8 \%$ in 2011 . It clearly reflects that quite a few people have actually moved from being cultivators to being agricultural laborers. 2011 Census results show a fall of about 9 million in cultivators and an increase of about 38 million in agricultural laborers.

Table 2 provides information on yield per hectare of major crops in India since 1950-1951.Yield per hectare of all food grains has increased by more than three-and-a-half tomes from $552 \mathrm{kgs}$ per hectare in 1950-1951 to 2016kgs per hectare in 2015-2016. Wheat has been recorded most significant increase since 1950-1951 with its yield increasing from $655 \mathrm{kgs}$ per hectare in 1950-1951 to $3093 \mathrm{kgs}$ per hectare in 2015-2016.Productivity of rice has also increased from 1950-1951 to $2404 \mathrm{kgs}$ per hectare in 2015-2016.Jowar and bajra recorded much slower rate s of growth in productivity. Productivity in pulses has shown much disappointing trend. The productivity of maize and cotton has been increased 
Table 2. Yield per hectare of major crops (Kgs per hectare).

\begin{tabular}{cccccccc}
\hline Crop & $1950-51$ & $1960-61$ & $1980-81$ & $1990-91$ & $2000-01$ & $2014-15$ & $2015-16$ \\
\hline Rice & 668 & 1013 & 1336 & 1740 & 1901 & 2390 & 2404 \\
Whear & 655 & 851 & 1630 & 2281 & 2708 & 2872 & 3093 \\
Jowar & 353 & 533 & 660 & 814 & 764 & 953 & - \\
Bajra & 288 & 286 & 458 & 658 & 688 & 1272 & - \\
Maize & 547 & 926 & 1159 & 1518 & 1822 & 2557 & - \\
Pulses & 441 & 539 & 473 & 578 & 544 & 744 & 652 \\
Total Food & 552 & 710 & 1023 & 1380 & 1626 & 2070 & 2056 \\
grains & & & & & & & \\
Oilseeds & 481 & 507 & 532 & 771 & 810 & 1037 & 968 \\
Cotton & 88 & 125 & 152 & 225 & 190 & 461 & 432 \\
Jute & 1043 & 1049 & 1245 & 1833 & 2026 & 2627 & - \\
\hline
\end{tabular}

Sources: (1) Various Economic Surveys; (2) RBI, Hand Book of Statistics on Indian Economy 2015-16.

substantially due to the adoption of hybrid maize varieties and Bt cotton in recent years. It is clear from the above table that the productivity of Maize rose from $547 \mathrm{kgs}$ per hectare in 1950-1951 to $2557 \mathrm{kgs}$ per hectare in 2014-2015.It is also observed from the above table that the average yield per hectare of pulses has grown by less than one percent annually on an average since the1950s.The productivity of jute has also increased from $1043 \mathrm{kgs}$ per hectare in 1950-1951 to $2627 \mathrm{kgs}$ per hectare in 2014-2015.Moreover, the target in respect of production of oilseeds was marginally exceeded but there were shortfall in realizing targets in except of sugarcane, jute, cotton etc.

Table 3 shows the India's position in the world agriculture in 2014.India has occupied seventh rank in terms of both in total area and land area in the world in 2014. India is the seventh largest country in the world with a total area of 329 million hectares. India is now the largest jute and pulses producer in the world and the second largest producer of Groundnut, sugarcane, tea and Cotton lint. As India is the largest consumer of these products, the quantity of exports varies depend on size of the crop and demand. But it is also a leading consumer. So although it exports these products the quantities will vary depending on the size of the crop and demand. India is the third largest producer of Tobacco manufactured products, Rapeseed and total cereals in 2014.

A comparison of Area, Production and productivity levels of various crops in Indian agriculture with other countries is presented in the above Table 4. It is observed from the above table that there were wider differences among various countries on the figures related to area, production and productivity of various crops. India accounted for percent of the total area.

It is quite evident from the above table that with respect to paddy production, China produces around $28 \%$ of the world paddy and India lies just below it producing $21.19 \%$ of the world paddy. India ranks second after China in the world paddy production. It is in a higher rank than Indonesia, Brazil and even 
Table 3. India's position in world agriculture in 2014.

\begin{tabular}{|c|c|c|c|c|c|}
\hline Item & India & World & \%share & ndia's Rank & Next to \\
\hline $\begin{array}{l}\text { 1) Total Area (Million } \\
\text { Hectares) }\end{array}$ & 329 & 13467 & 2.4 & Seventh & $\begin{array}{l}\text { Russian federation, Canada, } \\
\text { USA, China, Brazil, Australia }\end{array}$ \\
\hline a) Land Area & 297 & 13009 & 2.3 & Seventh & $\begin{array}{l}\text { Russian federation, China, USA, } \\
\text { Canada, Brazil, Australia }\end{array}$ \\
\hline b) Available Land & 156 & 1417 & 11.0 & Second & USA \\
\hline \multicolumn{6}{|l|}{$\begin{array}{l}\text { 2) Crop Production } \\
\text { (Million Tonnes) }\end{array}$} \\
\hline a) Total Cereals & 295 & 2819 & 10.5 & Third & China, USA \\
\hline b) Total Pulses & 20 & 78 & 25.8 & First & - \\
\hline \multicolumn{6}{|l|}{ c) Oilseeds } \\
\hline Groundnut (in shell) & 07 & 44 & 14.9 & Second & China \\
\hline Rapeseed & 08 & 74 & 10.7 & Third & Canada, China \\
\hline \multicolumn{6}{|l|}{ d) Commercial Crops } \\
\hline Sugarcane & 352 & 1884 & 18.7 & Second & Brazil \\
\hline Tea & 1.21 & 5.56 & 21.7 & Second & China \\
\hline Coffee (green) & 0.30 & 8.79 & 3.5 & Sixth & $\begin{array}{l}\text { Brazil, Vietnam, Indonesia, } \\
\text { Columbia, Ethiopia }\end{array}$ \\
\hline Jute \& Jute like Fibres & 2.07 & 3.65 & 56.8 & First & \\
\hline Cotton Lint & 6.19 & 26.16 & 23.7 & Second & China \\
\hline Tobacco Unmanufactured & 0.72 & 7.18 & 10.0 & Third & China, Brazil \\
\hline
\end{tabular}

Source: Agricultural Statistics at a glance 2016, P.254.

Table 4. Area production and yield of principal crops in various countries in 2014. (Area-“000" hectares, production-“000” Tonnes, Yield-Kg/Hectare).

\begin{tabular}{ccccc}
\hline Country & Area & production & Yield & Production (\%) \\
\hline World & & 1 . Paddy & & \\
China & 163,000 & 741,000 & 4546 & 100.00 \\
India & 30,300 & 207,000 & 6832 & 27.94 \\
Indonesia & 43,900 & 157,000 & 3576 & 21.19 \\
Bangladesh & 13,800 & 70,800 & 5130 & 9.55 \\
Thailand & 11,300 & 52,300 & 4628 & 7.06 \\
Myanmar & 10,700 & 32,600 & 3047 & 4.40 \\
Philippines & 6790 & 26,400 & 3888 & 3.56 \\
Brazil & 4740 & 19,000 & 4009 & 2.56 \\
Japan & 2341 & 12,200 & 5212 & 1.65 \\
& 1575 & 10,500 & 6667 & 1.42 \\
World & 220,000 & 2. Wheat & & \\
China & 24,100 & 157,000 & 3314 & 100.00 \\
India & 30,500 & 95,900 & 6515 & 21.54 \\
USA & 18,800 & 55,100 & 3144 & 13.16 \\
& & 3. Maize & 2931 & 7.56 \\
World & 185,000 & $1,040,000$ & 5622 & 100.00 \\
\hline
\end{tabular}




\section{Continued}

\begin{tabular}{|c|c|c|c|c|}
\hline USA & 33,600 & 361,000 & 10,744 & 34.71 \\
\hline China & 37,100 & 216,000 & 5822 & 20.77 \\
\hline Brazil & 15,400 & 79,900 & 5188 & 7.68 \\
\hline Argentina & 4837 & 33,100 & 6844 & 3.18 \\
\hline Ukraine & 4627 & 28,500 & 6160 & 2.74 \\
\hline India & 9258 & 23,700 & 2560 & 2.28 \\
\hline \multicolumn{5}{|c|}{ 4. Pulses } \\
\hline World & 85,191 & 77,473 & 909 & 100.00 \\
\hline India & 30,309 & 19,980 & 659 & 25.79 \\
\hline Myanmar & 4203 & 5977 & 1422 & 7.72 \\
\hline Canada & 2870 & 5828 & 2031 & 7.52 \\
\hline China & 2379 & 4101 & 1724 & 5.29 \\
\hline \multicolumn{5}{|c|}{ 5. Sugarcane } \\
\hline World & 27,100 & $1,880,000$ & 69,373 & 100.00 \\
\hline Brazil & 10,400 & 736,000 & 70,769 & 39.15 \\
\hline India & 5012 & 352,000 & 70,231 & 18.72 \\
\hline China & 1760 & 126,000 & 71,573 & 6.70 \\
\hline \multicolumn{5}{|c|}{ 6. Groundnut(in shell) } \\
\hline World & 26,500 & 43,900 & 1657 & 100.00 \\
\hline China & 4604 & 16,500 & 3584 & 37.59 \\
\hline India & 4685 & 6557 & 1400 & 14.94 \\
\hline \multicolumn{5}{|c|}{ 7. Tobacco Unmanufactured } \\
\hline World & 3964 & 7177 & 1811 & 100.00 \\
\hline China & 1463 & 2995 & 2047 & 41.74 \\
\hline Brazil & 416 & 862 & 2074 & 12.02 \\
\hline India & 433 & 721 & 1666 & 10.04 \\
\hline USA & 153 & 398 & 2596 & 5.54 \\
\hline
\end{tabular}

Source: FAOSTAT (as on 26-12-2016).

Japan, which roughly produces around $2 \%$ of the world paddy. Now taking about wheat, we can say that India produces around $13 \%$ of world wheat, which ranks just below China, which produces around 225 of world wheat. India ranks higher than even USA, which produces only around $8 \%$ of the world wheat. Coming to maize, USA ranks highest in the production of maize, producing $35 \%$ of world maize, followed by China, Brazil, Argentina, Ukraine and India. India ranks $6^{\text {th }}$ in the production of maize, producing $2.28 \%$ of world maize. Now speaking about pulses, India ranks in the production of pulses, producing around $26 \%$ of world pulses, followed by Myanmar, Canada and China. In terms of sugarcane, India ranks second after Brazil, producing 39\% of the world sugarcane, followed by China. With respect to groundnut, India lies second after China producing around $15 \%$ of world groundnut. Coming to unmanufactured tobacco, India ranks third, producing around $10 \%$ of the world tobacco, fol- 
lowed by USA. In terms of area wise cultivation of paddy, China covers an area of around $19 \%$ of the world paddy cultivation area. India ranks second with an area of around $27 \%$. In terms of cultivation of wheat, China covers an area of around $11 \%$ of the world wheat cultivation area. India ranks second with an area of around $27 \%$. In terms of cultivation of maize, USA covers an area of around $18 \%$ of the world maize cultivation area. India ranks second with an area of around 5\%. In terms of cultivation of pulses India ranks first, covering an area of $35.5 \%$ of the total world cultivation of pulses. In terms of cultivation of sugarcane India ranks second after Brazil, covering an area of $18.49 \%$ of the total world cultivation of pulses. In terms of cultivation of groundnut India ranks second after China, covering an area of $17.67 \%$ of the total world cultivation of groundnut. In terms of cultivation of tobacco India ranks third after China and Brazil, covering an area of $11 \%$ of the total world cultivation of tobacco.

\section{Trends in Agricultural Inputs}

The agricultural growth that India has experienced since independence is an outcome of efforts to ensure availability and use of high-quality seeds of high-yielding varieties; fertilizers; irrigation; pesticides; farm machinery and equipment; electricity and agricultural credit. Foremost among the agricultural inputs credited for revolutionizing the agricultural sector are improved seeds and planting materials.

Since independence, a huge amount of investment was made for the development of irrigation projects. In 1950-1951 about 20.9 million hectares of land were irrigated which accounted to only 18 percent of the total cropped area. Water and soil are the most important factors on which agriculture is based.

As a result of introduction of different sources of irrigation, irrigation potential of the country has increased from 81.1 million hectares in 1991-1992 to108.2 million hectares in March 2011 (Economic Survey 2010-2011).

The availability of irrigation at critical periods of crop growth is a major factor which determines the quality of crop produce. About 42 million hectares of land in India has assured irrigation facilities. The rest of the agricultural land mainly depends on monsoon or rainfall.

The use of fertilizers in Indian agriculture has received a boost after the initiation of high-Yielding Varieties Program me in 1966.The consumption of fertilizers has been increased from 66,000 tonnes in 1952-1953 to 125.46 lakh tones in 1990-1991 and in 2014-2015 stood at 255.76 lakh tonnes. India was emerged as the second largest consumer of fertilizers after China. But the imbalanced nutrient use coupled with neglect of organic matter has resulted in nutrition deficiencies in Indian soils. The average fertilizers consumption in India has increased from $69.84 \mathrm{~kg}$ per hectare in $1991-1992$ to $128.08 \mathrm{~kg}$ per hectare in 2014-2015. In the early 1950s the consumption of pesticides was negligible but in mid 1960s the use of pesticides increased considerably. The pesticides consumption in 1970-1971 stood at about 24.3 thousand tones and it rose to 57.4 thousand tonnes in 2014-2015. 
4. Empirical Analysis and Results:

\begin{tabular}{ccccc}
\hline Source & Sum of squares & $\begin{array}{c}\text { Degrees of } \\
\text { freedom }\end{array}$ & $\begin{array}{c}\text { Mean sum of } \\
\text { squares }\end{array}$ & $\begin{array}{c}\text { Number of } \\
\text { observations }=36\end{array}$ \\
Model & 412.003823 & 6 & 68.6673039 & $\mathrm{~F}(6,29)=6.05$ \\
Residual & 329.219234 & 29 & 11.3523874 & Probability $>\mathrm{F}=0.0003$ \\
Total & 741.223057 & 35 & 21.1778016 & R-squared $=0.5558$ \\
\hline GDP & Coefficient & Std Error & t value & Pvalue \\
\hline Fertilizers & -0.0125068 & 0.0449754 & -0.28 & 0.0783 \\
Net irrigated area & 0.000156 & 0.0004561 & 0.34 & 0.0735 \\
Pesticides & -0.0781709 & 0.0648877 & -1.20 & 0.0238 \\
Electricity & -0.0000741 & 0.0000838 & -0.88 & 0.0384 \\
Rainfall & 0.0430007 & 0.0076602 & 5.61 & 0.000 \\
Seeds & 0.0269377 & 0.0171984 & 1.57 & 0.0128 \\
constant & -33.85378 & 16.66425 & -2.03 & 0.051 \\
\hline
\end{tabular}

\section{GDP $=-33.85-0.0125$ fertilizers +0.00015 net irrigated area - \\ 0.078 pesticides -0.000074 electricity +0.043 rainfall +0.026 seeds $+\mu$}

The model is overall statistically significant $(P<0.05)$.

$\mathrm{R}$ Square value is 0.5558 , which means $55.58 \%$ of the variation in agricultural GDP is explained by the above mentioned independent variables.

The variables like fertilizers and net irrigated area are not statistically significant, which means they do not have a significant impact on agricultural GDP during the time period 1980-1981 to 2015-2016. The study further reveals that the variables like pesticides, electricity, rainfall and seeds are statistically significant and it is inferred that these variables have a significant impact on agricultural GDP during the aforementioned data period. Pesticides and electricity have a negative relationship with agricultural GDP. Rainfall and seeds have a positive impact on agricultural GDP. Due to $1 \%$ increase in pesticides use, agricultural GDP decreases by $0.078 \%$ and due to $1 \%$ increase in electricity, agricultural GDP decreases by $0.000074 \%$. Again due to $1 \%$ increase in rainfall, GDP increases by $0.043 \%$ and due to $1 \%$ increase in seeds use, agricultural GDP increases by $0.026 \%$. The error term accounts for the $45 \%$ variation in agricultural GDP that is not explained by the above taken independent variables.

\section{Robustness Tests}

Table 5 shows that, all the VIF values of the variables are within the threshold level of 1 - 10. So we can conclude, by saying that, there exists no Multicollinearity in the regression model. There is no linear relationship between the independent variables.

Next we apply the Breuch Pagan BP test to check for Heteroscedasticity in our regression model. Our analysis shows that our test statistic has a $\mathrm{P}$ value less 
Table 5. Values for Variance inflation factor (VIF) for Agriculture GDP.

\begin{tabular}{cc}
\hline Variables & Variance inflation factor (VIF) \\
\hline Fertilizers & 1.201 \\
Net irrigated area & 1.309 \\
Pesticides & 1.216 \\
Electricity & 1.177 \\
Rainfall & 2.673 \\
Seeds & 2.033 \\
\hline
\end{tabular}

than 0.05 , and then we can conclude by saying that there is no presence of heteroscedasticity, or unequal variance in our model.

Further we apply Durbin Watson DW test to check for autocorrelation in our model. Our analysis shows that DW test value is nearly 2 , which signifies there is no presence of autocorrelation.

So, all the three tests act as a robustness heck for our regression model. So we can say that our regression results are accurate and unbiased.

\section{Policy Implications \& Conclusions}

From the above discussion that it can be concluded that the variables like fertilizers and net irrigated area are not statistically significant, which means they do not have a significant impact on agricultural GDP during the time period 1980-1981 to 2015-2016 (Appendix). The study further reveals that the variables like pesticides, electricity, rainfall and seeds are statistically significant and it is inferred that these variables have a significant impact on agricultural GDP during the aforementioned data period. Pesticides and electricity have a negative relationship with agricultural GDP. Rainfall and seeds have a positive impact on agricultural GDP.

The government can intervene in the working of the agricultural sector both from input side as well as from output side. The government can directly supply the inputs like water, irrigation, power, seeds and fertilizers in adequate quantity at subsidized price. The government can also support the producers of agricultural commodities by ensuring reasonable price through procurement policy and minimum support policies. Market stabilization, price stabilization and supply of inputs shall be treated as the responsibilities of the government. Apart from the concerns related to food security and poverty alleviation government involvement is essential for creating exportable surplus through adequate investment on infrastructure, irrigation, agricultural research and extension etc.

The government of India and many state governments have been investing huge amount on major and medium irrigation projects since 1951, but the beneficiaries of these projects have not been asked to pay for it. Even the running cost of these projects is not being met by the payment made by the users of these projects. The government has to regulate the consumption of ground water levels and registering of pump sets should be made compulsory on the part of the 
farming community. Water shed projects as well as construction of minor irrigation and maintenance of age-old water resources shall be placed in the hands of farming community. Investment on water resource development especially the conservation and consolidation of traditional water resources should receive immediate attention.

The policy of cheap input can be justified in the initial phases of development and that to when the beneficiaries belong to low-income groups. The policy of providing free power to all the farming community will also have severe consequences like decline of ground water due to over utilization of groundwater. The government has to regulate the consumption of ground water levels and registering of pump sets should be made compulsory on the part of the farming community. Water shed projects as well as construction of minor irrigation and maintenance of age-old water resources shall be placed in the hands of farming community.

Government has to expand the agricultural research and extension activity and the peasants are to be prepared to face future challenges in scientific manner. Reviving public sector investment is critical due to its multiplier effect on the overall GCF in the sector. Thus, there is a need to formulate a long-term perspective plan for rural infrastructure that focuses on infrastructural projects that have the highest total impact and strongest linkages.

\section{References}

[1] Puri, V.K. and Misra, S.K. (2017) Indian Economy. 35th Edition, Himalaya Publishing House, Mumbai, 139.

[2] Economic Survey (2017-2018) Ministry of Finance, GOI.

[3] Dwivedy, N. (2011) Challenges Faced by the Agriculture Sector in Developing Countries with Special Reference to India. International Journal of Rural Studies, 18, 2-7.

http://www.vri-online.org.uk/ijrs/Oct2011/Challenges\%20faced\%20by\%20the\%20A griculture\%20Sector\%20in\%20India

[4] De Gorter, H. and Swinnen, J. (2002) Political Economy of Agricultural Policy. In: Gardner, B.L. and Rausser, G.C., Eds., Handbook of Agricultural Economics, Vol. 2B, North Holland, Amsterdam, 1893-1943.

[5] Kuznets (1968) Toward a Theory of Economic Growth with Reflections on the Economic Growth of Modern Nations. Norton, New York.

[6] NCAER (2015) Kharif Outlook Report. Report No. 2015-12-1.

[7] Bardhan, P.K. (1970) The Green Revolution and Agricultural Labourers: A Correction. Economic and Political Weekly, 5, 1861-1862.

[8] Staatz, J.M. and Dembele, N.N. (2007) Agriculture for Development in Sub-Saharan Africa. Background Paper for the World Development Report, World Bank, Washington DC.

[9] Garg, J.S., Singh, G.N. and Srivastava, H.L. (1970) Impact of High-Yielding Varieties of Crops on Patterns of Income Distribution. Indian Journal of Agricultural Economics, 25, 115-121.

[10] Dhingra, I.C. (2010) The Indian Economy, Environment and Policy. Sultan Chand and Sons, Educational Publishers, New Delhi, 312. 
Appendix: All Units Are \% Growth Rates

\begin{tabular}{|c|c|c|c|c|c|c|c|}
\hline Year & Fertilizers \% & Seeds\% & $\begin{array}{c}\text { Net Irrigated } \\
\text { Area\% }\end{array}$ & Pesticides\% & Electricity\% & Rainfall\% & GDP\% \\
\hline 1980 & 0.0993 & 0.0172 & 0.0460 & 0.0444 & 0.0059 & -0.0274 & 12.9 \\
\hline 1981 & 0.0534 & -0.0334 & 0.0046 & 0.0638 & -0.0116 & -0.1349 & 4.6 \\
\hline 1982 & 0.2070 & 0.0692 & 0.0309 & 0.1000 & 0.0234 & 0.3051 & -0.3 \\
\hline 1983 & 0.0650 & 0.0781 & 0.0047 & 0.0182 & 0.1495 & -0.1415 & 10.1 \\
\hline 1984 & 0.0320 & 0.1347 & -0.0066 & -0.0714 & 0.1175 & -0.0318 & 1.6 \\
\hline 1985 & 0.0202 & 0.0149 & 0.0168 & -0.0385 & 0.2571 & -0.0752 & 0.3 \\
\hline 1986 & 0.0161 & 0.0084 & 0.0076 & 0.3380 & 0.1978 & 0.0061 & -0.4 \\
\hline 1987 & 0.2568 & 0.0089 & 0.0759 & 0.1344 & 0.1024 & 0.4125 & -1.6 \\
\hline 1988 & 0.0478 & 0.0042 & 0.0120 & -0.0513 & 0.1332 & -0.1591 & 15.6 \\
\hline 1989 & 0.0845 & 0.0011 & 0.0283 & 0.0417 & 0.1422 & 0.0568 & 1.2 \\
\hline 1990 & 0.0145 & 0.0070 & 0.0384 & -0.0383 & 0.1637 & -0.1481 & 4 \\
\hline 1991 & -0.0452 & 0.0492 & 0.0086 & -0.0186 & 0.0815 & 0.0041 & -2 \\
\hline 1992 & 0.0175 & 0.0310 & 0.0207 & -0.1009 & 0.1164 & 0.0890 & 6.7 \\
\hline 1993 & 0.0969 & 0.0588 & 0.0323 & -0.0360 & 0.1217 & 0.1054 & 3.3 \\
\hline 1994 & 0.0231 & 0.0613 & 0.0076 & -0.0016 & 0.0811 & -0.1008 & 4.7 \\
\hline 1995 & 0.0311 & 0.0482 & 0.0320 & -0.0841 & -0.0200 & 0.0387 & -0.7 \\
\hline 1996 & 0.1314 & 0.0753 & 0.0018 & -0.0690 & 0.0860 & -0.0083 & 9.9 \\
\hline 1997 & 0.0377 & 0.0784 & 0.0403 & -0.0590 & 0.0652 & 0.0170 & -2.6 \\
\hline 1998 & 0.0757 & 0.0354 & 0.0017 & -0.0602 & -0.0644 & -0.0848 & 6.3 \\
\hline 1999 & -0.0757 & -0.0194 & -0.0404 & -0.0567 & -0.0682 & -0.0341 & 2.7 \\
\hline 2000 & 0.0393 & 0.0641 & 0.0314 & 0.0789 & -0.0361 & -0.0142 & 0 \\
\hline 2001 & -0.0729 & 0.0679 & -0.0534 & 0.0272 & 0.0344 & -0.1029 & 6 \\
\hline 2002 & 0.0438 & 0.1077 & 0.0586 & -0.1511 & 0.0308 & 0.2471 & -6.6 \\
\hline 2003 & 0.0952 & 0.1075 & 0.0381 & -0.0080 & 0.0168 & -0.1580 & 9 \\
\hline 2004 & 0.1055 & 0.0540 & 0.0271 & -0.0221 & 0.0196 & 0.1293 & 0.2 \\
\hline 2005 & 0.0645 & 0.2230 & 0.0313 & 0.0438 & 0.0967 & 0.0172 & 5.1 \\
\hline 2006 & 0.0424 & 0.1551 & 0.0071 & 0.0511 & 0.0521 & 0.0604 & 4.2 \\
\hline 2007 & 0.1036 & 0.2053 & 0.0071 & 0.0053 & 0.0345 & -0.0692 & 5.8 \\
\hline 2008 & 0.0633 & 0.1914 & -0.0267 & -0.0465 & 0.1087 & -0.2045 & 0.1 \\
\hline 2009 & 0.0618 & 0.0787 & 0.0278 & 0.3281 & 0.0576 & 0.3049 & 0.8 \\
\hline 2010 & -0.0118 & 0.0631 & 0.0320 & -0.0461 & 0.1154 & -0.0109 & 8.6 \\
\hline 2011 & -0.0811 & 0.0630 & 0.0087 & -0.1389 & 0.0461 & -0.0861 & 5 \\
\hline 2012 & -0.0413 & -0.0384 & 0.0277 & 0.3214 & -0.0220 & 0.1382 & 1.4 \\
\hline 2013 & 0.0447 & 0.0057 & -0.0135 & -0.0486 & 0.0113 & -0.1661 & 4.2 \\
\hline 2014 & -0.0214 & -0.0029 & 0.0068 & 0.0253 & -0.0056 & -0.0203 & -0.2 \\
\hline 2015 & -1.0000 & -1.0000 & -1.0000 & -1.0000 & -1.0000 & -1.0000 & 1.1 \\
\hline
\end{tabular}

